\title{
1 Influence of Plant Coverage on the Total Green Roof Energy Balance
}

\section{2 and Building Energy Consumption}

3 Neda Yaghoobian* (neyaghoo@gmail.com), Jelena Srebric (jsrebric@umd.edu)

4 Department of Mechanical Engineering, University of Maryland, College Park, MD, USA

$5 \quad$ *Corresponding author; current address: Department of Mechanical Engineering, Johns Hopkins

6 University, Baltimore, MD 21218, USA

8 Abstract

9 This study quantifies the influence of green roof plant coverage on the building energy consumption and the substrate energy balance components. The analysis started with the

11 implementation of a green roof model that accounts for the effects of plant coverage into the U.S.

12 Department of Energy (DOE) building energy simulation program, EnergyPlus. Using the DOE

13 reference building models, thirty different cases were simulated considering different green roof

14 plant coverage, building type, and building age for two different climates. The results indicated

15 that the green roof substrate surface temperature decreases with increasing plant coverage. This temperature decrease is primarily due to the decrease in the amount of absorbed solar radiation on

17 the substrate surface and also an increase in the substrate surface evaporation. For the base-case

18 simulation, due to the plant shading effects, the total daily received radiation at the bare-soil surface is $32 \%\left(6.2 \mathrm{kWh} \mathrm{m}^{-2}\right)$ higher than that at the fully-covered green roof substrate surface.

20 Furthermore, the annual cooling (heating) load decreases (increases) with the rate of $13(0.88)$

$21 \mathrm{kWh} \mathrm{m}^{-2}$ of plant coverage area. The aim of this study is to show the importance of considering 22 plant coverage in green roof simulations and building energy demand predictions.

24 Keywords: Building energy simulation, Green roof, Plant coverage, Surface energy balance 


\section{1. Introduction}

26 As the human population grows, many more natural surfaces turn into impervious surfaces to

27 support infrastructure development for the city dwellers [1,2]. Replacing the natural land cover

28 with buildings and impervious surfaces changes the local energy balance due to different radiative

29 and thermal properties of the newly-introduced materials. These modifications create a different

30 microclimate in the urban areas compared to the microclimate in the rural areas. Turning traditional

31 black flat roofs that constitute about $20-25 \%$ of the urban surfaces [3] into green roofs is one of

32 the potential solutions to restore some of natural habitats destroyed in the process of developing

33 city infrastructure. Green roofs are one of the oldest and well-known techniques to reduce the

34 negative effects of urbanization and have been recognized as one of the Urban Heat Island (UHI)

35 mitigation strategies [4]. Green roofs can mitigate the effects of impervious surfaces such as storm

36 water runoff $[5,6]$, and higher surface and ambient air temperatures [7, 8]. Therefore, green roofs

37 offer multiple benefits to cities from the water and energy flow perspectives. Urban- and building-

38 scale benefits and positive effects of green roofs have been explored in several studies using

39 numerical simulations, field measurements and laboratory experiments [9-16]. In their lifecycle,

40 green roofs are not continuously fully-covered with plants resulting in heterogeneity along the

41 green roof surfaces. Heterogeneity in roughness, shading, and soil moisture content creates

42 nonuniformity in energy and mass transport over green roofs. In practice, to reduce the green roof

43 heterogeneity and to speed plant growth rate at the initial period of a green roof lifecycle, pre-

44 cultivated vegetation mats are used [17]. Therefore, studying the green roof heterogeneity and

45 plant coverage effects on the green roof energy balance and building energy consumption is

46 required to understand the performance of green roofs. 
47 An extensive literature review indicates that despite a long history of valuable studies in the area

48 of green roofs, the effects of the green roof plant coverage (defined as the percentage of the roof

49 area covered with plants to the total green roof area) have not been studies, quantitatively.

50 Most of the detailed existing green roof models account for the effects of the plant canopy height

51 and density [18-20], but due to the horizontally-homogeneous assumptions, heterogeneity effects

52 along the green roof surfaces are neglected. Heterogeneity in green roof plant coverage is explicitly

53 considered in a recently developed model by Tabares-Velasco and Srebric [14] (hereinafter GR-

54 TS2012). GR-TS2012 is a physically-based, quasi-steady state heat and mass transfer green roof

55 model that introduced the plant coverage as a percentage of the total green roof area. The aim of

56 the current study is to use a modified version of GR-TS2012 to explore and quantify the effects of

57 plant coverage on the extensive type green roof surface energy balance and further explore its

58 influence on the energy demand in buildings. Therefore, GR-TS2012 was implemented into

59 EnergyPlus, the U.S. Department of Energy (DOE) building energy simulation program [21]. If

60 successfully implemented, this simulation module can enable numerical calculations of green roof

61 plant coverage impacts on the building energy consumption. Therefore, beyond the model

62 implementation, this study validated the module with data from measurements and conducted

63 simulations of thirty different cases considering different green roof plant coverage, building type,

64 and building age for two different climates. Overall, the study deployed a detailed green roof model

65 in a comprehensive way to quantitatively evaluate impacts of the green roof plant coverage on the

66 total green roof energy balance and the thermal performance of a building. 


\begin{tabular}{|c|c|}
\hline \multicolumn{2}{|c|}{ Nomenclature } \\
\hline$C_{p}$ & Specific heat of air, $\mathrm{J} \mathrm{kg}^{-1} \mathrm{~K}^{-1}$ \\
\hline$e_{\text {air }}$ & Vapor pressure in the air, $\mathrm{kPa}$ \\
\hline$e_{\text {soil }}$ & Saturated vapor pressure at the soil/substrate temperature, $\mathrm{kPa}$ \\
\hline$h_{\text {conv }}$ & Convective heat transfer coefficient for plant layer, $\mathrm{W} \mathrm{m} \mathrm{m}^{-2} \mathrm{~K}^{-1}$ \\
\hline$h_{\text {por }}$ & Convective heat transfer coefficient for porous media (plants), $\mathrm{W} \mathrm{m}^{-2} \mathrm{~K}^{-1}$ \\
\hline$h_{\text {sub }}$ & Total convective heat transfer coefficient for green roof substrate, $\mathrm{W} \mathrm{m} \mathrm{m}^{-2} \mathrm{~K}^{-1}$ \\
\hline$k_{l}$ & Longwave extinction coefficient \\
\hline$k_{s}$ & Shortwave extinction coefficient \\
\hline$L A I$ & Leaf area index $[($ leaf area $) /$ (soil surface) $]$ \\
\hline$L M S T$ & Local Mean Sidereal Time \\
\hline$L W_{\text {net_Plant }}$ & $\begin{array}{l}\text { Thermal radiative exchange between the plant layer and the soil surface } \\
\text { absorbed by the soil surface, } \mathrm{W} \mathrm{m}^{-2}\end{array}$ \\
\hline$L W_{\text {net_Sky }}$ & $\begin{array}{l}\text { Thermal radiative exchange between the sky and the soil surface absorbed by } \\
\text { the soil surface, } \mathrm{W} \mathrm{m}^{-2}\end{array}$ \\
\hline$Q_{E}$ & Substrate surface latent heat flux, $\mathrm{W} \mathrm{m} \mathrm{m}^{-2}$ \\
\hline$Q_{E \_b a r e}$ & Substrate latent heat flux of the uncovered portions of the green roofs, $\mathrm{W} \mathrm{m}^{-2}$ \\
\hline$Q_{E_{-} \text {covered }}$ & Substrate latent heat flux of the covered portions of the green roofs, $\mathrm{W} \mathrm{m}^{-2}$ \\
\hline$Q_{G}$ & Conductive heat flux through green roof substrate and roof construction, $\mathrm{W} \mathrm{m} \mathrm{m}^{-2}$ \\
\hline$Q_{S}$ & Substrate surface sensible heat flux, $\mathrm{W} \mathrm{\textrm {m } ^ { - 2 }}$ \\
\hline$r_{a}$ & Aerodynamic resistance to mass transfer, $\mathrm{s} \mathrm{m}^{-1}$ \\
\hline$r_{\text {sub }}$ & Substrate surface resistance to mass transfer \\
\hline$R_{S}$ & Total shortwave radiation received at the substrate surface, $\mathrm{W} \mathrm{m}^{-2}$ \\
\hline$S W_{\text {net }}$ & Substrate surface net absorbed shortwave radiation, $\mathrm{W} \mathrm{m}^{-2}$ \\
\hline$T_{\text {plant }}$ & Plant temperature, $\mathrm{K}$ \\
\hline$T_{\text {sky }}$ & Sky temperature, $\mathrm{K}$ \\
\hline$V W C$ & Substrate average volumetric water content, $\mathrm{m}^{3} \mathrm{~m}^{-3}$ \\
\hline$V W C_{\text {sat }}$ & Substrate maximum volumetric water content, $\mathrm{m}^{3} \mathrm{~m}^{-3}$ \\
\hline \multicolumn{2}{|l|}{ Greek } \\
\hline$\gamma$ & Psychrometric constant, $\mathrm{kPa} \mathrm{K}^{-1}$ \\
\hline$\delta_{f}$ & Plant coverage $(\mathrm{PC})$ \\
\hline$\varepsilon_{g}$ & Soil emissivity \\
\hline$\varepsilon_{p}$ & Plant emissivity \\
\hline$\varepsilon_{S}$ & Sky emissivity \\
\hline$\rho$ & Air density, $\mathrm{kg} \mathrm{m}^{-3}$ \\
\hline$\tau_{l w}$ & Longwave transmittance of a plant canopy \\
\hline$\tau_{s w}$ & Shortwave transmittance of a plant canopy \\
\hline
\end{tabular}




\section{Model description}

71 This study uses a quasi-steady state heat and mass transfer green roof model that was developed

72 from data collected in a "Cold Plate" apparatus set in an environment chamber [22]. The detailed

73 description of this model, which in this paper is referred to as GR-TS2012, is available in the

74 literature [14]. This model is fully validated with laboratory and field experimental data including

75 both heat fluxes and surface temperature fields $[14,23]$. The unique characteristic of this

76 physically-based model is the ability to simulate partially-exposed/partially-covered, including

77 bare-soil and fully-covered green roofs by taking into account the plant coverage percentage. GR-

78 TS2012 was originally implemented in the Engineering Equation Solver (EES) software to solve

79 the heat and mass transfer equations between the sky, plants and substrate. In order to investigate

80 the effects of a green roof plant coverage on building energy performance in this study, GR-

81 TS2012 was integrated into the U.S. Department of Energy (DOE) building energy simulation

82 software, EnergyPlus [21]. EnergyPlus is one of the most advanced building energy simulation

83 models that is supported by DOE for analyzing the energy consumption of buildings. EnergyPlus

84 is a stand-alone building energy simulation model that simulates the hourly energy consumption

85 of a building conditional on user-specified internal loads, building construction, and weather. More

86 information about EnergyPlus can be found in the corresponding DOE publications [24, 25]. For

87 implementing GR-TS2012 into EnergyPlus, GR-TS2012 was written in FORTRAN and later in

$88 \mathrm{C}++$ language. In its new format, the energy balance equations for plants, bare soil surface, and

89 substrate surface under the plant layer were solved iteratively for their temperatures by Newton's

90 method. Furthermore, using the plant coverage percentage, the area-averaged soil surface

91 temperature is calculated as the roof surface temperature. The volumetric water content (VWC) in

92 the substrate layer is simulated by the moisture-tracking subroutine of EnergyPlus that accounts 
93 for precipitation, irrigation, evapotranspiration, and runoff [20]. Similar to the existing 'Ecoroof'

94 model option in EnergyPlus, in the current model, the user is allowed to specify a green roof layer

95 as the outer layer of a rooftop construction [20]. Besides the 'Ecoroof' inputs that include growing

96 media depth, soil physical and thermal properties, plant canopy density, stomatal resistance, and

97 soil moisture conditions, additional parameters are required for the new green roof model. The

98 new parameters are the plant coverage representing the percentage of green roof area covered with

99 plants, the substrate VWC at field capacity, as well as the shortwave and longwave extinction

100 coefficients [26]. GR-TS2012 requires additional inputs, but they are crucial in accounting for

101 thermal effects of partially covered green roofs.

102 To verify the implementation of the green roof model into EnergyPlus, the model was tested 103 against field data from a green roof installed on a commercial building roof in Chicago, IL, the 104 same case that was used in the previous field validation study of GR-TS2012 [23]. Recreation of 105 the GR-TS2012 validation study verified that the implemented model into EnergyPlus works as 106 expected.

107

108 3. Simulation setup

109 Energy performance of buildings in response to the green roof plant coverage depends on several 110 factors such as local climate, building use type, building age, as well as the green roof material 111 and the roof assembly underneath the green roof. These factors are considered as the key input 112 parameters for the building energy simulations to enable direct performance comparisons.

114 3.1 Scenarios for climate, building type, building age, and green roof plant coverage 
115 Thermal performance of green roof assemblies depends on the local climate because the green roof 116 material properties are highly dependent on outdoor environmental conditions [19,27]. A study of

117 the green roof thermal performance showed that the material selection for green roof assemblies

118 is more important in climate zones 4 and 5 than the material selection for buildings located in 119 climate zones 2 and 3 [27]. Based on these finding, the present study used the typical 120 meteorological year (TMY2 [28]) weather data files for Baltimore, Maryland (39.17 ${ }^{0}$ north 121 latitude, $76.67^{\circ}$ west longitude and $47 \mathrm{~m}$ altitude) located in climate zone 4 with mixed-humid 122 climate and Phoenix, Arizona $\left(33.42^{\circ}\right.$ north latitude, $112.02^{\circ}$ west longitude and $339 \mathrm{~m}$ altitude $)$ 123 located in climate zone 2 with hot- to mixed-dry climate to represent different environmental 124 conditions.

125 The U.S. Department of Energy (DOE) developed commercial reference building models that 126 consist of sixteen building types, and represent approximately two-thirds of the U.S. commercial 127 building stock. These model buildings feature realistic building characteristics and construction 128 practices that provide a consistent baseline for comparison of building energy simulations [29]. 129 Among these building types, this study used one-story buildings that include small office and 130 stand-alone retail buildings. Previous studies showed that office buildings and retail stores are the 131 commercial building types with the largest amount of energy use in the U.S. [30].

132 The energy use in single-story buildings strongly depends on the roof insulation that could also 133 limit the energy saving benefits of green roofs for buildings with well-insulated roofs. Older 134 buildings with poorly insulated roofs are expected to benefit more from green roofs than newer135 built buildings with a higher level of insulation [11, 31-33]. To address the effects of green roof 136 plant coverage on buildings with different levels of insulation, the DOE commercial reference 137 building models for all three categories of new-construction, post-1980, and pre-1980 buildings 
138 [34] were used in this study. The differences among these buildings are reflected in the insulation

139 levels, infiltration rates, lighting intensities, as well as HVAC equipment types and efficiencies.

140 The new-construction models comply with the minimum requirements of ANSI/ASHRAE/IESNA

141 Standard 90.1-2004 [35], the post-1980 models meet the minimum requirements of Standard 90.1-

1421989 [36], and pre-1980 models are based on previous standards and other studies of construction

143 practices [29].

144 Considering that green roof plants take several months to become fully established, and the roofs

145 may not stay fully covered during their lifespans, it is desirable to study a range of green roof 146 growth coverage rates from bare-soil to fully-covered roofs. For this reason, the plant coverage

$147\left(\delta_{f}\right)$ of $0 \%$ (bare soil), $25 \%, 50 \%, 75 \%$, and $100 \%$ (fully covered with plants) was considered in 148 this study.

149

\subsection{Conventional and green roof assembly materials}

151 As stated in the previous section, this study examined the three categories of new-construction, 152 post-1980, and pre-1980 buildings of small office and stand-alone retail buildings from the DOE 153 commercial reference building models [34] in Baltimore, MD and Phoenix, AZ. Energy 154 performance of these buildings were modeled with and without an additional set of layers for the 155 green roof. Based on the DOE commercial reference buildings, roofs of the stand-alone retail 156 buildings in all three categories of new-construction, pre- and post-1980 buildings, plus pre-1980 157 small office buildings are the same and of the type of 'Insulation Entirely Above Deck (IEAD) 158 non-residential' roof, but the thickness of their insulation layers is different. In new-construction 159 and post-1980 small office buildings, roofs are of the type of 'attic non-residential' roofs. The 160 building roof types are the same for both Baltimore and Phoenix. IEAD non-residential roofs 
161 consist of three layers including the roof membrane, IEAD non-residential roof insulation, and

162 metal decking. Attic non-residential roofs consist of two layers including the roof membrane, and

163 metal decking. Roof types and physical characteristics of their material layers are provided in

164 Table 1. Sketch of the layers of the IEAD non-residential, attic non-residential, and green roofs

165 are presented in the Appendix.

166

167 TABLE 1. Thicknesses and properties of the roof material layers for the DOE reference buildings in Baltimore, MD.

168 Roof material properties in Phoenix, AZ are the same as the material properties in Baltimore, MD except the material

169 thicknesses provided in parentheses. This table is based on the DOE reference building models [34].

\begin{tabular}{ccccc}
\hline Material layer & Thickness (m) & $\begin{array}{c}\text { Conductivity } \\
\left(\mathrm{W} \mathrm{m}^{-1} \mathrm{~K}^{-1}\right)\end{array}$ & $\begin{array}{c}\text { Density } \\
\left(\mathrm{kg} \mathrm{m}^{-3}\right)\end{array}$ & $\begin{array}{c}\text { Specific heat } \\
\left(\mathrm{J} \mathrm{kg}^{-1} \mathrm{~K}^{-1}\right)\end{array}$ \\
\hline $\begin{array}{c}\text { Roof membrane } \\
\text { Metal decking }\end{array}$ & 0.0095 & 0.16 & 1121.3 & 1460 \\
$\begin{array}{c}\text { IEAD non-res insulation (New } \\
\text { const. - Retail) }\end{array}$ & 0.0015 & 45 & 7680 & 418.4 \\
$\begin{array}{c}\text { IEAD non-res insulation (Post- } \\
\text { 1980 - Retail) }\end{array}$ & $0.136(0.175)^{*}$ & 0.05 & 265 & 836.8 \\
$\begin{array}{c}\text { IEAD non-res insulation (Pre- } \\
\text { 1980 - Office) }\end{array}$ & $0.088(0.074)^{*}$ & 0.05 & 265 & 836.8 \\
$\begin{array}{l}\text { IEAD non-res insulation (Pre- } \\
\text { 1980 - Retail) }\end{array}$ & $0.088(0.074)^{*}$ & 0.05 & 265 & 836.8 \\
\hline
\end{tabular}

$170 *$ Numbers in parentheses are material thicknesses in Phoenix, AZ.

171 For a set of realistic simulations, the construction assembly of green roof is defined based on an

172 extensive type green roof located in Chicago, Illinois used in the previous validation study of GR-

173 TS2012 [23], and also in a green roof material study [27]. The green roof material layers, which

174 are placed over the conventional roofs, and their physical characteristics are presented in Table 2.

175 Table 3 includes the green roof soil and plant canopy data. The green roof characteristics were

176 kept constant in all of the simulations.

177

178 TABLE 2 . The green roof material layers from top to bottom [10, 23, 27, 37-40] 


\begin{tabular}{cccccc}
\hline Layer name & Layer type & $\begin{array}{c}\text { Thickness } \\
(\mathrm{m})\end{array}$ & $\begin{array}{c}\text { Thermal } \\
\text { conductivity } \\
\left(\mathrm{W} \mathrm{m}^{-1} \mathrm{~K}^{-1}\right)\end{array}$ & $\begin{array}{c}\text { Density } \\
\left(\mathrm{kg} \mathrm{m}^{-3}\right)\end{array}$ & $\begin{array}{c}\text { Specific heat } \\
\left(\mathrm{J} \mathrm{kg}^{-1} \mathrm{~K}^{-1}\right)\end{array}$ \\
\hline Substrate & Expanded clay & 0.075 & 0.32 & 682 & 1065 \\
$\begin{array}{c}\text { Filter } \\
\text { membrane }\end{array}$ & $\begin{array}{c}\text { Two layers of } \\
\text { polypropylene } \\
\text { fabric layers }\end{array}$ & 0.002 & 0.137 & 900 & 1926 \\
$\begin{array}{c}\text { Drainage } \\
\text { layer }\end{array}$ & $\begin{array}{c}\text { Recycled closed } \\
\text { cell polystyrene }\end{array}$ & 0.025 & 0.033 & 25 & 1046 \\
$\begin{array}{c}\text { Waterproof } \\
\text { membrane }\end{array}$ & PVC & 0.002 & 0.19 & 1370 & \\
\hline
\end{tabular}

179

180 TABLE 3. Information of the green roof soil and plant canopy [14, 23, 27]

\begin{tabular}{l|l}
\hline Plant type & Mixed sedum species \\
Plant albedo & 0.11 \\
Soil albedo & 0.12 \\
Minimum stomatal resistance & $700 \mathrm{~s} \mathrm{~m}^{-1}$ \\
Leaf area index $(L A I)$ & $2.5\left(\mathrm{~m}^{2} \mathrm{~m}^{-2}\right)$ \\
Shortwave extinction coefficient $\left(k_{s}\right)$ & 0.7 \\
Longwave extinction coefficient $\left(k_{l}\right)$ & 0.83 \\
Leaf emissivity & 0.98 \\
Soil emissivity & 0.95 \\
Substrate maximum volumetric water content $\left(V W C_{s a t}\right)$ & $0.55\left(\mathrm{~m}^{3} \mathrm{~m}^{-3}\right)$ \\
Substrate volumetric water content at field capacity & $0.33\left(\mathrm{~m}^{3} \mathrm{~m}^{-3}\right)$ \\
\hline
\end{tabular}

182 4. Results and discussion

183 To study the importance of the green roof plant coverage, it is necessary to explore its effects on 184 the green roof energy balance components individually, and on the substrate surface temperature 185 as a whole. In addition, studying the annual and diurnal variations of building energy use with 186 respect to the change in the green roof plant coverage in different buildings and climates 187 illuminates the importance of this parameter in building energy simulations. For these reasons, the 188 influence of plant coverage on both the total green roof energy balance and building energy 
189 consumption were examined in the simulations. Since the energy balance analysis of snow layers 190 is not considered in the current versions of GR-TS2012 and EnergyPlus, the diurnal results of this

191 study are restricted to the summertime. Unless stated otherwise, all the diurnal results are monthly 192 averages for the typical meteorological month of July in Phoenix with average wind speed of 3.6 $193 \mathrm{~m} \mathrm{~s}^{-1}$, average relative humidity of $35 \%$, average air temperature of $33^{\circ} \mathrm{C}$, and low cloud coverage 194 in average. July month is selected to be representative of midsummer. The pre-1980 small office 195 building is considered as the base-case simulation.

197 4.1 Importance of considering the green roof plant coverage in green roof 198 simulations

199 To calculate a green roof substrate surface temperature and investigate its effects on building 200 energy use, it is necessary to understand the energy balance for the green roof. In general, the 201 temperature of the green roof substrate surface is not uniform and varies across the green roof 202 depending primarily on the amount of plants covering the soil surface. In the current green roof 203 model implemented in EnergyPlus, the green roof substrate surface temperature at each time step 204 is computed as an area-averaged temperature based on the bare-soil and the covered-soil surface 205 temperatures. Similarly, the heat fluxes at the green roof are area-averaged heat fluxes of both the 206 bare and vegetated roof areas. The average substrate surface temperature represents the roof 207 surface temperature used in the building energy simulations. The importance of plant coverage for 208 green roof simulations is investigated by comparing the results of the substrate surface energy 209 balance for the bare-soil and fully-covered green roofs. The following equation shows the energy 210 balance for a green roof soil surface:

$211 S W_{\text {net }}+L W_{\text {net_Sky }}+L W_{\text {net_Plant }}=Q_{S}+Q_{E}+Q_{G}$ 
212 where $S W_{\text {net }}$ is the net absorbed shortwave radiation by the substrate surface, $L W_{\text {net_sky }}$ is the net 213 exchange of longwave radiation between the sky and the soil absorbed by the soil surface,

$214 L W_{\text {net_Plant }}$ is the net exchange of longwave radiation between the plant layer and the soil surface 215 absorbed by the soil surface that is zero for a bare-soil roof, $Q_{S}$ and $Q_{E}$ are the sensible and latent 216 convective heat fluxes over the substrate surface, and $Q_{G}$ is the conductive heat flux through the 217 substrate and roof construction layers. Unlike the energy balance components for the bare-soil 218 roof, the energy balance components for the fully-covered green roof are affected by the plant 219 layer.

221 4.1.1 Plant coverage effects on the total received radiation at the substrate surface

222 The following equations represent the total amount of radiation $\left(\operatorname{Rad}_{\text {Total }}\right)$ received at the surface 223 of bare-soil, fully-covered, and partially covered green roofs in GR-TS2012 [14]:

$225 \operatorname{Rad}_{\text {Total_bare }}=R_{s}+\varepsilon_{s} \sigma T_{\text {sky }}^{4}$

$226 R_{\text {Total_covered }}=\tau_{s w} R_{s}+\tau_{l w} \varepsilon_{s} \sigma T_{s k y}^{4}+\left(1-\tau_{l w}\right) \frac{\varepsilon_{p} \varepsilon_{g}}{\varepsilon_{p}+\varepsilon_{g}-\varepsilon_{p} \varepsilon_{g}} \sigma T_{p l a n t}^{4}$

$227 \operatorname{Rad}_{\text {Total_partial }}=\delta_{f} \cdot \operatorname{Rad}_{\text {Total_covered }}+\left(1-\delta_{f}\right) \cdot \operatorname{Rad}_{\text {Total_bare }}$

228 where $R_{s}$ is the total shortwave radiation received at the substrate surface, $\varepsilon_{s}\left(\varepsilon_{p}\right)$ and $T_{\text {sky }}\left(T_{\text {plant }}\right)$ 229 are the sky (plant) emissivity and temperature, $\varepsilon_{g}$ is the soil emissivity, $\tau_{s w}$ and $\tau_{l w}$ are the 230 shortwave and longwave transmittance of a canopy, $\sigma$ is the Stefan-Boltzmann constant, and $\delta_{f}$ is 231 the plant coverage ratio. In the simulations, $R_{s}$ and $T_{s k y}$ are hourly inputs from the EnergyPlus 232 TMY2 weather data file for Baltimore and Phoenix. 
233 The amount of shortwave radiation received at the substrate surface underneath the plant layer is 234 the sum of the un-intercepted radiation and the radiation that is transmitted and/or reflected by the 235 canopy leaves. Furthermore, the longwave radiation is the sum of un-intercepted sky thermal 236 radiation and the radiation emitted by the plant layer. The shortwave transmittance of a canopy $237\left(\tau_{s w}\right)$ is $e^{-k_{s} L A I}$ [14], where $k_{s}$ is the extinction coefficient and $L A I$ is the leaf area index. The 238 transmittance of thermal radiation $\left(\tau_{l w}\right)$ is the radiation that is not intercepted by any leaf and is 239 calculated similar to $\tau_{s w}$, but with a different extinction coefficient $\left(k_{l}\right)$ [14]. For the base-case, 240 Fig. 1 compares monthly averaged diurnal results of the received shortwave, longwave, and total 241 incoming radiation at the soil surface of green roofs with different plant coverage (PC) for the 242 month of July in Phoenix. The differences in the received radiation for the bare-soil and fully243 covered green roofs are significant as shown in Fig. 1. 
a) Received SW radiation at the substrate surface

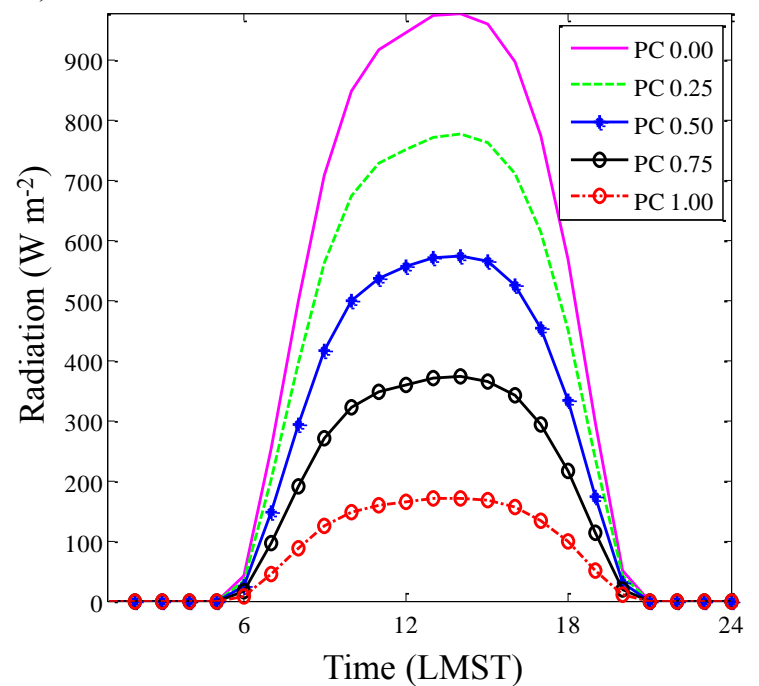

b) Received LW radiation at the substrate surface

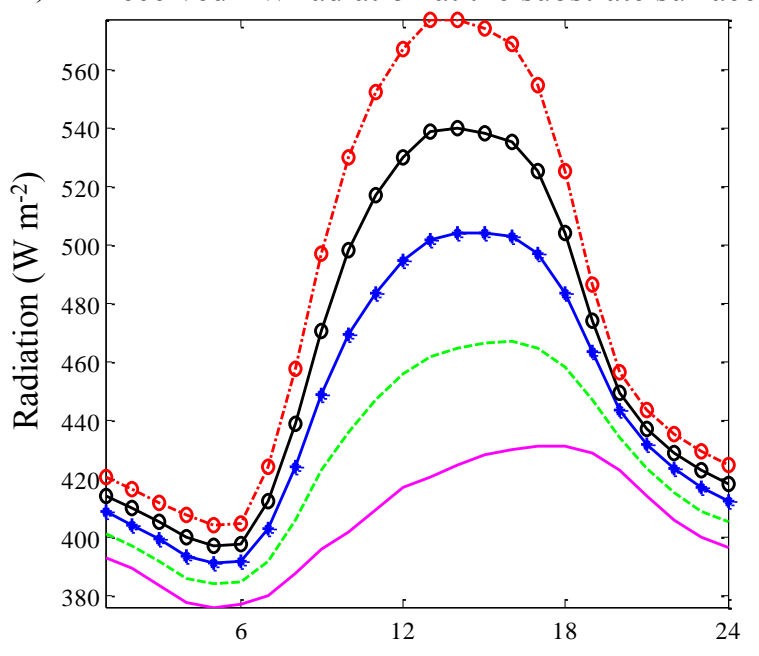

Time (LMST)

c) Total received radiation at the substrate surface

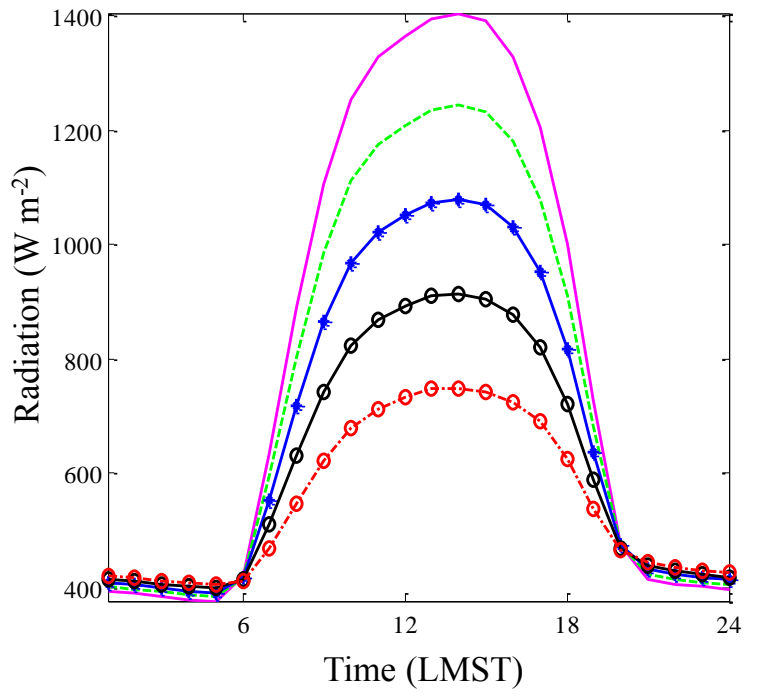


FIG. 1. Monthly averaged diurnal results of a) shortwave, b) longwave, and c) total radiation received at the green roof substrate surface with the plant coverage (PC) of $0.0,0.25,0.5,0.75$, and 1.0 for the month of July in Phoenix, AZ for the base-case simulation. LMST stands for the Local Mean Sidereal Time.

Due to the plant shading effects, the received shortwave radiation at the substrate surface of a fullycovered green roof is much smaller than that over the bare-soil with the total difference of $83 \%$ as shown in Fig. 1a. This amount is highly dependent on the plant density of the canopy that, in the green roof model, is accounted through the $L A I$ variable, and the canopy shortwave extinction coefficient. Density of the plant canopy depends on several factors (e.g. plant type, weather condition, water availability) and is variable throughout a year and at different geographical locations. For the same reason, the amount of received sky thermal radiation is smaller at the soil surface covered by the plants. However, since the plant layer and the underneath soil surface have thermal interactions, the total amount of incoming longwave radiation at the soil surface covered by the plants is $19 \%$ larger than the amount of longwave radiation received at the bare-soil surface (Fig. 1b). Furthermore, Fig. 1c reveals that the total amount of radiation over $24 \mathrm{~h}$ period for a bare-soil roof is $19.4 \mathrm{kWh} \mathrm{m}^{-2}$ that is $6.2 \mathrm{kWh} \mathrm{m}^{-2}$ larger than the total radiation received at the substrate surface of a fully-covered green roof. In another word, the daily integrated value of the received total radiation at the substrate surface of a bare-soil roof can have up to $32 \%$ error, if the plant coverage effects are not considered in the green roof simulations.

\subsubsection{Plant coverage effects on the substrate surface convective heat fluxes}

The amounts of plant coverage affect sensible and latent heat fluxes over the substrate surfaces of green roofs. In general, existence of a plant layer makes the substrate convective heat transfer more complex, and in simulations, this complexity reflects on the convective heat transfer coefficient. 
269 The following equation represents the general form of the sensible heat transfer coefficient over

270 the soil surface of a fully-covered green roof $\left(h_{s u b}\right)$ in GR-TS2012 [14]:

$271 \quad h_{\text {sub }}=h_{\text {por }} \cdot h_{\text {conv }} /\left(h_{\text {por }}+h_{\text {conv }}\right)$

272 In Eq. (5), $h_{\text {conv }}$ is a function of the Nusselt number for the forced, mixed, and natural convection

273 on a flat surface and $h_{\text {por }}$ accounts for the sheltering and roughness effects of the plant layer. The

274 details of the $h_{\text {sub }}$ calculation can be found in [14].

275 Figure 2a shows monthly averaged diurnal cycles of the substrate sensible heat transfer coefficients

276 for green roofs of the base-case with different plant coverage. Figure $2 \mathrm{~b}$ shows wind speed at the

277 roof height for the month of July in Phoenix. Figure 2 indicates that the soil sensible heat transfer

278 coefficients significantly decrease with increasing plant coverage, and they follow the trend of the

279 wind speed at the roof height. The sensible heat transfer is a complex dynamic phenomena that 280 depends on several parameters, but the correlation between this coefficient and wind speed shown

281 in Fig. 2 indicates that a reduced wind speed in the foliage layer is the main reason for the smaller 282 convective heat transfer coefficients over the covered green roofs.
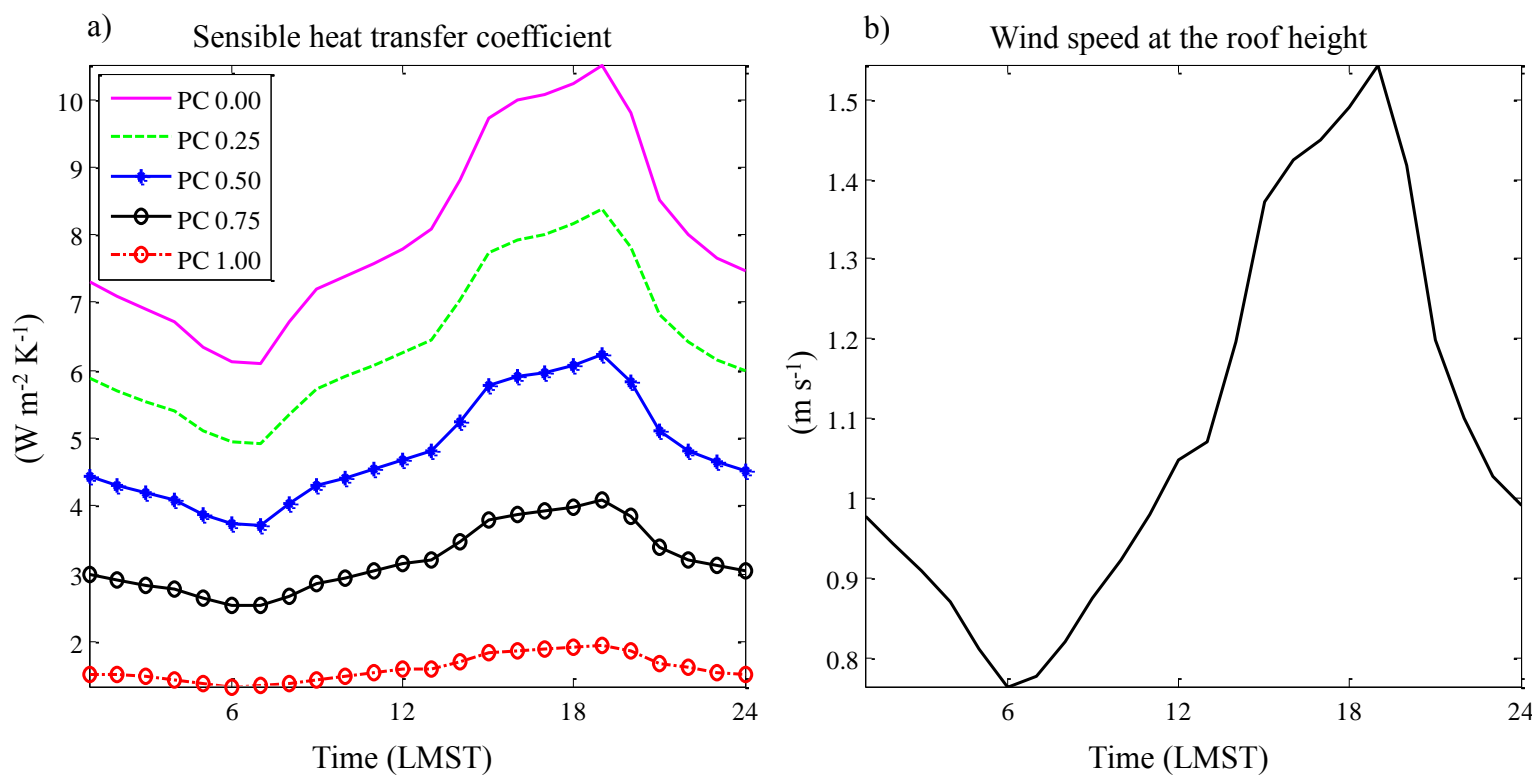
FIG. 2. Monthly averaged diurnal results including a) sensible heat transfer coefficients for green roofs with plant coverage (PC) of $0.0,0.25,0.5,0.75$, and 1.0, and b) wind speeds at the roof height for the month of July in Phoenix, AZ for the base-case simulation.

Generally, the water vapor removal from the soil surface is subjected to the vapor pressure difference of the air layer and the soil surface, as well as the air speed over the soil surface and within the plant canopy. In GR-TS2012, the evaporation rate from the soil surface $\left(Q_{E}\right)$ is calculated using the following equation [14]:

$Q_{E}=\frac{\rho C_{p}}{\gamma\left(r_{\text {sub }}+r_{a}\right)}\left(e_{\text {soil }}-e_{\text {air }}\right)$

where $\rho$ and $C_{p}$ are the density and specific heat of air, $\gamma$ is the psychrometric constant, $e_{\text {soil }}$ is the saturated vapor pressure at the soil temperature, $e_{\text {air }}$ is the vapor pressure in the air, $r_{a}$ is the aerodynamic resistance to mass transfer that accounts for the sheltering and roughness effects of the plant layer. $r_{\text {sub }}\left(=34.5\left(\frac{V W C}{V W C_{\text {sat }}}\right)^{-3.3}\right)$ is the substrate surface resistance to mass transfer that depends on the ratio of the average substrate volumetric water content $(V W C)$ and the substrate volumetric water content at saturation $\left(V W C_{\text {sat }}\right)$; specifically, the drier the soil, the larger the resistance to water vapor.

To understand the plant coverage effects on the complex and dynamic process of the substrate evaporation, Figs $3 \mathrm{a}$ and $3 \mathrm{~b}$ respectively show the substrate surface latent heat fluxes from the areas of green roofs with and without plants. Furthermore, Fig. 3c shows the area-averaged substrate latent heat fluxes for green roofs with different plant coverage. Figure $3 \mathrm{~d}$ represents the near surface moisture content for the base-case that is dynamically simulated by the moisturetracking subroutine of EnergyPlus.

Figure $3 b$ shows that, similar to the substrate latent heat flux of the covered portions of the green roofs, $Q_{E_{-} \text {covered }}$ (Fig. 3a), the substrate latent heat flux of the uncovered portions of the green 
308 roofs, $Q_{E_{-} b a r e}$, increases with increasing plant coverage percentage. That is because the energy

309 balance for the bare and covered portions of a green roof are not independent and they interact 310 dynamically. The elevated soil surface latent heat fluxes with increasing plant coverage are 311 consistent with the fact that the average near-surface moisture level with larger plant coverage is 312 larger (Fig. 3d). However, comparing Figs 3a and 3b indicates that the evaporation from the 313 uncovered portions of the green roofs is larger than that over the covered portions by a factor of 3. 314 That is because over the bare soils the air speed is larger and thus the aerodynamic resistance to 315 mass transfer is smaller. That explains the behavior of the area-averaged substrate latent heat flux 316 that is defined by $Q_{E_{-} \text {covered }}+\left(1-\delta_{f}\right) Q_{E_{-} b a r e}$ for the green roofs with different plant coverage 317 in Fig. 3c. This figure shows that the latent heat flux over the fully-covered green roof in the base318 case simulation is smaller than that over the $75 \%$ - and 50\%-covered green roofs, and its maximum 319 is similar to that of the $25 \%$-covered green roof, except for the time lag of few hours. 

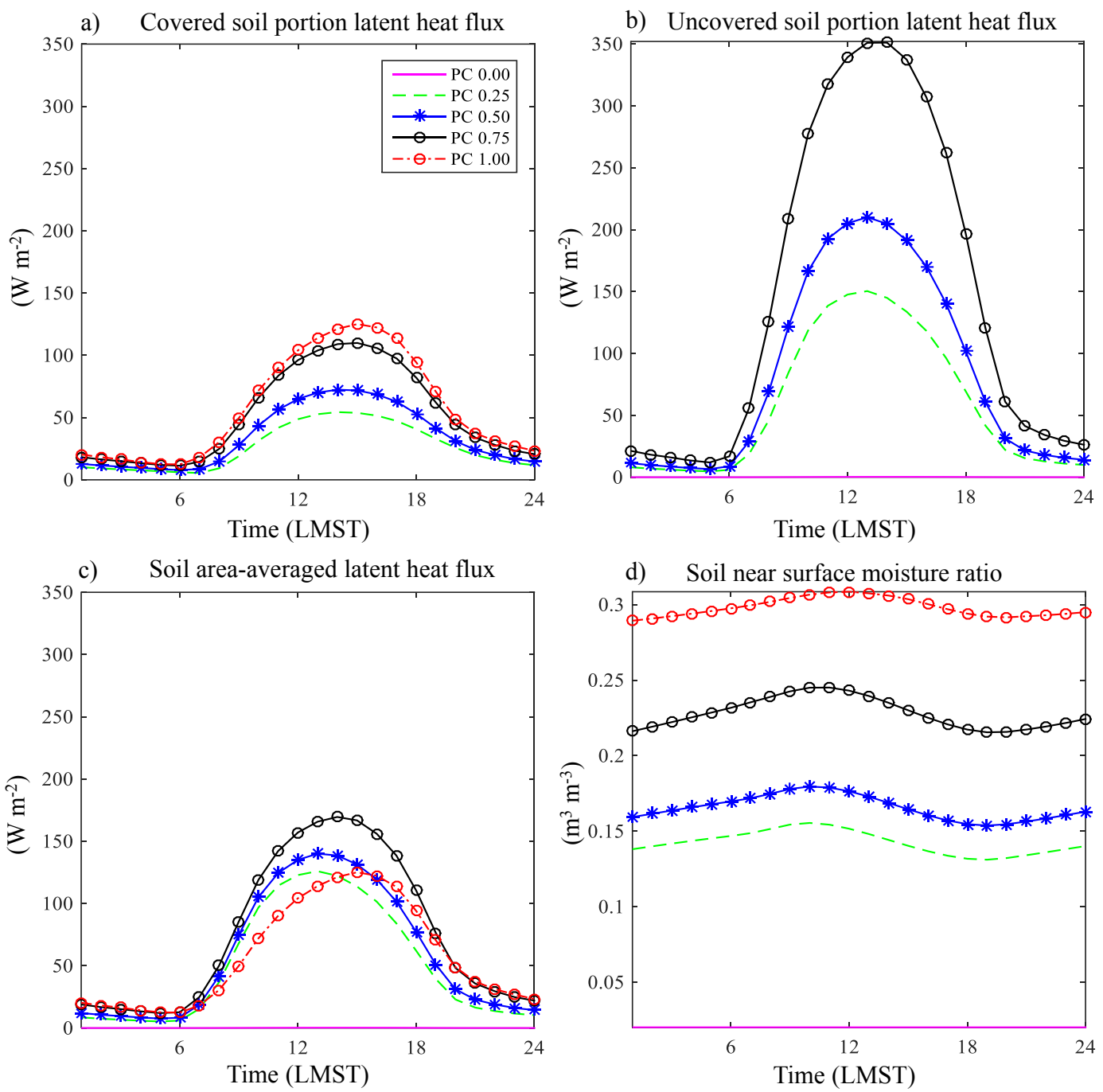

FIG. 3. Monthly averaged diurnal results including a) covered soil, b) uncovered soil, and c) soil average latent heat

322 fluxes, and d) moisture content near the soil surface of green roofs with plant coverage (PC) of 0.0, 0.25, 0.5, 0.75,

323 and 1.0 for the month of July in Phoenix, AZ for the base-case simulation.

4.1.3 Plant coverage effects on the conductive heat flux

326 Conduction is a complex process that depends on the soil material properties, surface and deep-

327 soil temperatures, as well as the soil moisture content. A larger amount of moisture in the soil media increases the soil conductivity. Thus, in response to the soil moisture content, the average soil thermal properties vary. Convective process via water movement within the soil layers is small 
330 and negligible. As Fig. 3d shows, the amount of soil moisture varies with plant coverage. However, 331 due to the use of the EnergyPlus conduction model (Conduction Transfer Functions; CTFs), these

332 effects are not considered in the current green roof study, meaning that the substrate thermal 333 properties do not vary in response to the soil moisture content. The reason is that the CTFs 334 coefficients for each type of material are determined only once at the beginning of the simulations 335 and they remain unchanged during the simulations. Variable thermal properties of the materials 336 cause numerical instabilities in the CTF simulation method. Therefore, in the new green roof 337 simulation module in EnergyPlus, the soil conduction response to the plant coverage only depends 338 on the substrate surface temperature. Previous studies showed that seasonal and hourly variations 339 of thermal conductivity have a relatively small impact on the overall thermal performance of a 340 green roof when compared to the effects of radiation and evapotranspiration [22, 41]. Moreover, 341 several validation studies indicated that GR-TS2012 is accurate even with the constant soil thermal 342 properties $[14,23]$.

$344 \quad$ 4.1.4 Green roof substrate surface temperatures

345 Figure 4 compares substrate surface temperatures of green roofs with different plant coverage for 346 the pre-1980 small office building (the base-case simulation) for a typical July day in Phoenix. 347 This figure shows that the soil surface temperature decreases with increasing plant coverage. That 348 is primarily due to the larger amount of received shortwave radiation and consequently the larger 349 amount of total absorbed shortwave radiation at the substrate surfaces of the less covered green 350 roofs. The smaller near surface moisture content in less covered green roofs and their smaller 351 amounts of latent heat flux are the second important reason for their higher surface temperatures. 
352 Based on Fig. 4, for the base-case, the substrate surface temperature difference between the fully-

353 covered and bare-soil roofs reaches $24^{\circ} \mathrm{C}$ at $1400 \mathrm{LMST}$. In another word, green roof models 354 considering only the fully-covered green roof surfaces may predict the substrate surface 355 temperature of a bare-soil roof with an error of up to $34 \%$.

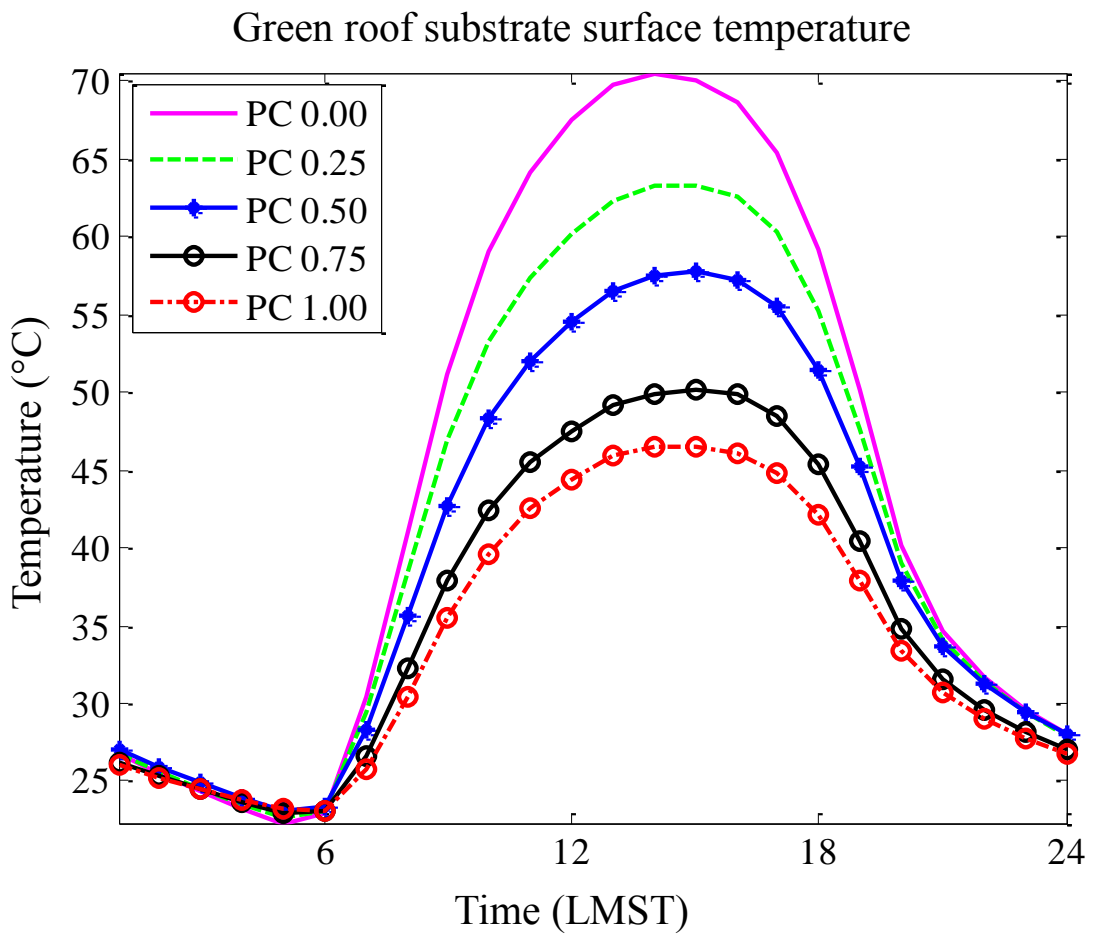

358 FIG. 4. Monthly averaged diurnal cycle of substrate surface temperatures for green roofs with plant coverage (PC) of $3590.0,0.25,0.5,0.75$, and 1.0 for the month of July in Phoenix, AZ for the base-case simulation.

\subsection{Building energy consumption}

362 Figure 5 shows annual thermal loads of new-construction, post-, and pre-1980 buildings with 363 respect to change in green roof plant coverage for the two building types, small office and stand364 alone retail, in Baltimore and Phoenix. This figure shows that for all cases the annual cooling loads 365 decrease with the increasing plant coverage, and the annual heating loads increase with the 
366 increasing plat coverage. However, the decrease in annual cooling demands overweigh the

367 increase in annual heating demands in all cases. Furthermore, due to the weaker roof insulation,

368 thermal loads of the buildings built before 1980, are more sensitive to the change in the plant

369 coverage (Figs 5e and 5f). In all simulated cases, the annual cooling loads of the buildings in

370 Phoenix are larger and more sensitive to the plant coverage than the annual cooling loads of the

371 buildings in Baltimore. In addition, the annual heating loads in Baltimore are larger than the annual

372 heating loads in Phoenix. For the pre- and post-1980 buildings, the sensitivity of annual cooling

373 loads to the plant coverage in office buildings is larger than the sensitivity in retail buildings.

374 However, in the new-construction building, this annual cooling load sensitivity to the plant

375 coverage is larger for the retail buildings compared to the sensitivity for the office buildings. These

376 trends are related to the relative dependence of thermal loads on the building type and age which

377 are reflected in the roof heat gains/losses, internal heat gains, and infiltration rates.

378 Aside from the plant coverage effects on building energy use, Fig. 5 also reveals that the pre-1980

379 buildings require the highest amount of heating and cooling energy, followed by the requirements

380 for the post-1980 buildings and new-constructions. The energy demand differences between these

381 buildings are related to their differences in insulation levels, lighting intensities, and infiltration

382 rates. 

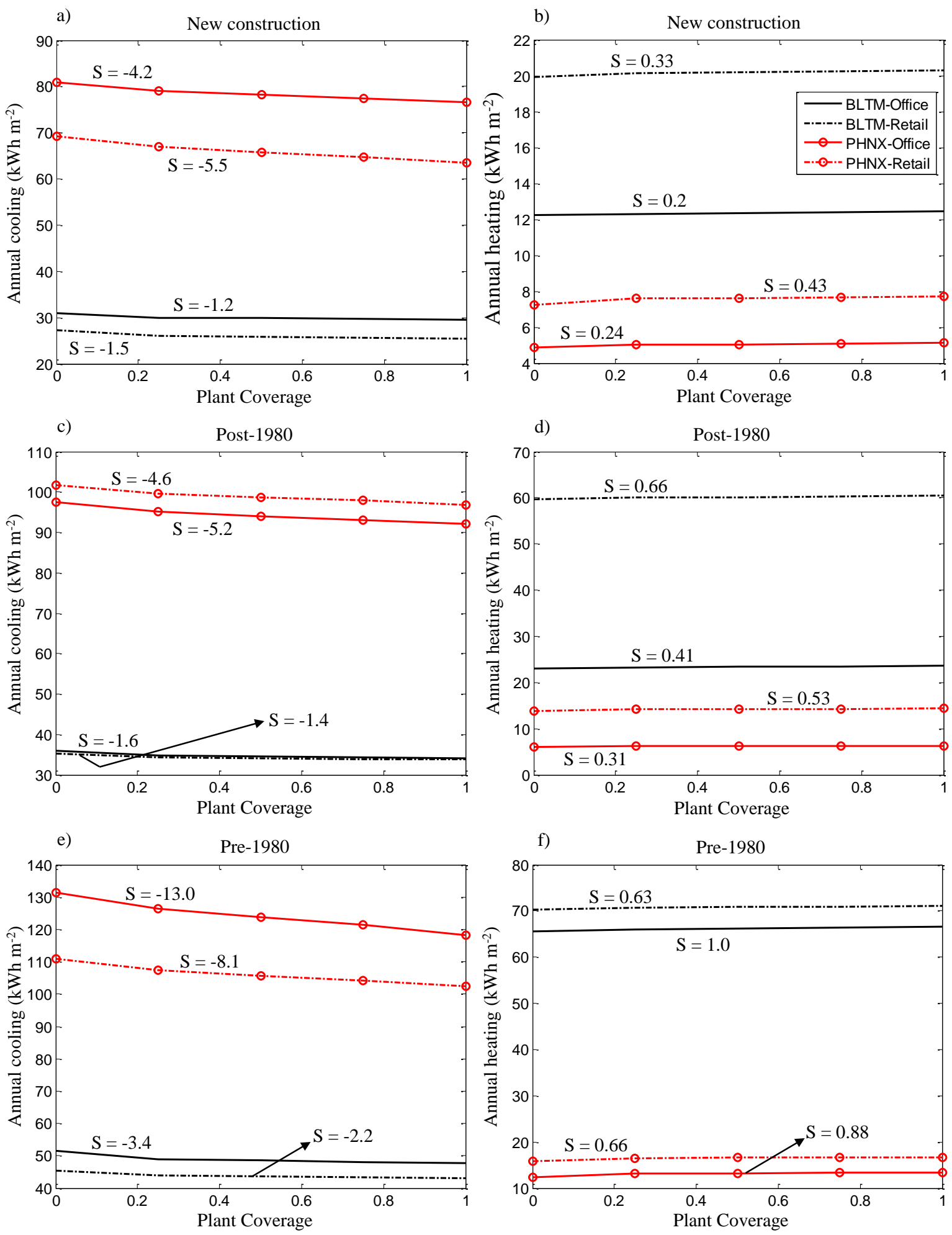

FIG. 5. Annual cooling (left column) and annual heating (right column) loads for the new-construction (a, b), post1980 (c, d), and pre-1980 (e, f) small office and stand-alone retail buildings in Baltimore, Maryland (black lines) and 
Phoenix, Arizona (red lines). $S$ is the slope for the annual thermal loads with respect to the green roof plant coverage in $\mathrm{kWh} \mathrm{m}^{-2}$ per plant coverage change from 0 to 1 .

\subsubsection{Effects of the plant coverage}

Figure 5 indicates that for buildings of any age and type, a change in the annual thermal loads with respect to a change in the plant coverage can be defined by a linear equation. The slope of the lines $(S)$, representative of the sensitivity of the annual thermal loads to plant coverage, vary with the type and age of a building and also with climate. To better understand the heat transfer behavior of the green roofs, monthly averaged diurnal cycle of roof surface temperatures, ceiling heat fluxes, and building cooling demands for the month of July in Phoenix are presented in Fig. 6. In this study, only the summer results are discussed because based on the annual results, cooling loads responded strongly to the increase in plant coverage, while the increase in heating loads did not have so strong response to the plant coverage. In Fig. 6, the simulation results are presented for the small office buildings which in most cases showed the largest cooling load sensitivity to the change in plant coverage. Since the roof assembly of the new-construction and post-1980 office buildings are similar (attic roofs, but with different infiltration rates in the attic zone) their heat transfer processes are comparable. Therefore, here only the monthly averaged results for the newconstruction as the less sensitive case are compared against the monthly averaged results for the pre-1980 building as the most sensitive case. These results are for the Phoenix climate that revealed the largest annual cooling demand and sensitivity to the plant coverage. For comparison purposes, the results of the same cases, but with a conventional roof assembly are also presented in Fig. 6. Since the annual thermal loads demonstrated a linear relation with the plant coverage, only the monthly averaged results of 0.0, 0.25, and 1.0 plant coverage rate simulations are shown in Fig. 6. 

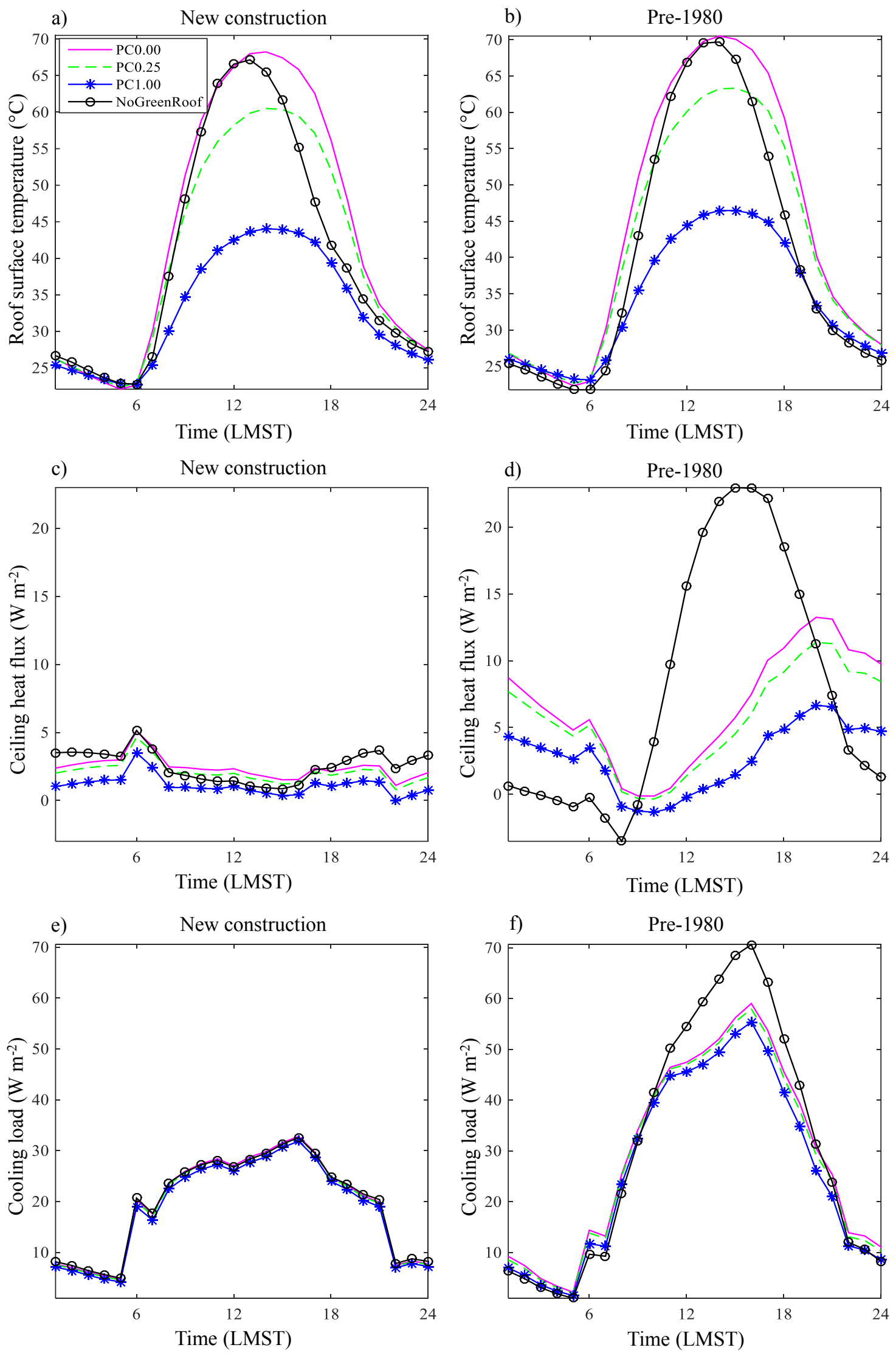
411 FIG. 6. Comparisons of the monthly averaged roof surface temperatures (a, b), ceiling heat fluxes (c, d), and cooling 412 loads (e, f) for the new-construction (left column) and pre-1980 (right column) small office buildings for the month 413 of July in Phoenix, AZ. Ceiling heat fluxes and cooling loads are in Watt per square meter of floor area.

415 The results in Fig. 6 shows that the green roof soil surface temperatures and as a result the amounts 416 of ceiling heat fluxes and cooling loads decrease with increasing plant coverage. The bare-soil roof 417 is the warmest, followed by $25 \%$ - and fully-covered green roofs. During the day, there is a small 418 difference between the maximum surface temperature of the bare-soil roof and that of the 419 conventional roof. However, mainly due to the direct exposure to solar radiation, both of these 420 surfaces are significantly warmer than the substrate surface of the fully-covered green roof. The 421 substrate surface temperature difference between the fully-covered and bare-soil roofs is up to 24.3 $422{ }^{\circ} \mathrm{C}$ at $1300 \mathrm{LMST}$ for the new-construction (Fig. 6a), and $24{ }^{\circ} \mathrm{C}$ at $1400 \mathrm{LMST}$ for the pre-1980 423 building (Fig. 6b). These temperature differences tend to diminish at nighttime. At nighttime, due 424 to the longwave radiation trapping between the plant layer and the soil surface, the soil surface 425 lose less heat to the surrounding air and as a result remains relatively warm.

426 The degree of the influence of green roof plant coverage on the cooling demand of a building 427 depends on the roof contribution in the total building thermal loads. For the new-construction 428 office buildings in Phoenix, a decrease in total daily cooling load in summer from a bare-soil roof 429 to a fully-covered green roof is $4.5 \%$. This amount shows a degree of potential simulation error, if 430 the plant coverage is not considered. This error can reach $8.9 \%$ for the pre-1980 office buildings. 431 Unlike the new-construction buildings, in the pre-1980 buildings, due to the weak insulation of the 432 roof assemblies, even a bare-soil green roof significantly affects the amount of cooling demand. 433 The decrease in total daily cooling loads between the conventional roof and the bare-soil roof for 434 the pre-1980 building is $5.8 \%$, whereas this difference in the new-construction is negligible. 
437 Roof surface temperatures affect the indoor building climate and energy demand directly through

438 the ceiling heat fluxes and indirectly by modifying the outdoor air temperature. Due to the 439 EnergyPlus limitations, the latter is not considered in this study. The amount of ceiling heat flux 440 itself depends on the construction material and the roof type. The roof type in the DOE new441 construction reference small office building is attic roof, while the pre-1980 buildings have flat 442 roofs with insulation above a deck. This difference in roof type explains the different trends in the 443 ceiling heat fluxes of the new-construction and pre-1980 buildings as shown in Figs 6c and 6d. 444 The roof type also resulted in the lower peak roof surface temperatures for the new-construction 445 building in Fig. 6a when compared to the peak temperatures for the pre-1980 buildings as shown 446 in Fig. 6b. The lower roof surface temperatures in the new-construction buildings are related to 447 the smaller thermal resistance of the attic roof (consists of two layers including the roof membrane, 448 and metal decking) compared to that of the insulated roof in the pre-1980 buildings (consist of 449 three layers including the roof membrane, IEAD non-residential roof insulation, and metal 450 decking), and larger heat conduction into the attic space.

451 The large volume of air inside the attic space works as a strong insulator in the new-construction 452 buildings, stronger than the insulation layer in the pre-1980 buildings. As a result, the amount of 453 ceiling heat flux is much smaller in the new-construction building than that in the pre-1980 454 buildings (Figs 6c and 6d). Because of this strong insulator in new-construction, the ceiling heat 455 flux has around a 17 hour time lag compared to the roof outside surface temperature, meaning that 456 a change in the roof surface temperature after 1300 LMST is affecting the ceiling heat flux after $4570600 \mathrm{LMST}$. This time lag for the post-1980 buildings is around $12 \mathrm{~h}$ and in the pre-1980 buildings 458 is much shorter being $3 \mathrm{~h}$ for the conventional roof and $6 \mathrm{~h}$ for the green roofs. Larger roof surface 
temperatures of green roofs with zero and $25 \%$ plant coverage compared to the conventional roof 460 of the new-construction after 1300 LMST in Fig. 6a, result in larger amount of the ceiling heat 461 flux between 0600 LMST and 1800 LMST in Fig. 6c (17 h later). Figures 6a and 6b show that the 462 green roof has the peak surface temperatures delayed compared to those temperatures for the 463 conventional roof because of the larger thermal inertia due to additional green roof layers. For the 464 same reason, fluctuations of the ceiling heat fluxes are smaller in the presence of a green roof.

465 As mentioned earlier, roof construction materials are partially responsible for the degree of 466 sensitivity of building types to the change in plant coverage (Fig. 5). For example, the roof 467 insulation of new-construction retail building is thinner than that of the post-1980 retail building 468 (Table 1). As a result, the cooling demand of new-construction retail buildings is more sensitive 469 to the plant coverage.

470 As shown in Figs 6c and 6d, there is a large difference between heat fluxes through the insulated 471 flat roof in the pre-1980 office buildings and the attic roof in the new-construction office buildings. 472 Thermal behavior of these two different types of roofs is very different. Figure 7 compares the 473 heat gain through the ceiling and the total cooling loads of the new-construction and pre-1980 474 office buildings with conventional roofs in $\mathrm{W} \mathrm{m}^{-2}$ of floor area for a typical summer day in 475 Phoenix. Figure 7 shows that in the new-construction buildings the strong roof insulation creates 476 a significant time lag for the maximum ceiling heat gain. In the new-construction buildings with 477 conventional roof, the maximum ceiling heat gain of $5.2 \mathrm{~W} \mathrm{~m}^{-2}$ occurs at $0600 \mathrm{LMST}$. At the same 478 time, with the zero plant coverage and fully covered green roofs, the maximum ceiling heat gain 479 reduces to 5.1 and $3.5 \mathrm{~W} \mathrm{~m}^{-2}$, respectively (not shown). In the pre-1980 office buildings with the 480 conventional roof assembly, the maximum ceiling heat gain of $23 \mathrm{~W} \mathrm{~m}^{-2}$ occurs at $1500 \mathrm{LMST}$. 
481 This maximum value reduces to $13.2 \mathrm{~W} \mathrm{~m}^{-2}$ at $2000 \mathrm{LMST}$ for the bare-soil roof and $6.6 \mathrm{~W} \mathrm{~m}^{-2}$ at 4822000 LMST for the fully-covered green roof (not shown).

483 For a typical summer day in the pre-1980 office buildings with the conventional roof, the daily 484 integrated value of ceiling heat gain and cooling loads are $198 \mathrm{Wh} \mathrm{m}^{-2}$ and $742 \mathrm{Wh} \mathrm{m}^{-2}$ of floor 485 area, respectively. In the new-construction buildings, the daily ceiling heat gain and cooling loads 486 are $62 \mathrm{Wh} \mathrm{m}^{-2}$ and $468 \mathrm{Wh} \mathrm{m}^{-2}$ of floor area, respectively. This indicates that the contribution of 487 ceiling heat gain in the total daily cooling loads of the pre-1980 office buildings is twice as that in 488 the new-construction (26\% versus $13 \%)$. Thus, green roofs and their plant coverage are more 489 important and effective in these older office buildings. For the buildings with conventional roofs, 490 Table 4 compares the daily integrated values of ceiling heat gains, cooling loads, and ceiling 491 thermal contributions in the total cooling demands during a typical summer day in Phoenix. This 492 table indicates that the smaller ceiling thermal contributions in the total cooling loads is related to 493 the attic type roofs in the new-construction and post-1980 small office buildings. The larger ceiling 494 contribution in the total daily cooling demand is related to the new-construction stand-alone retail 495 building. Nevertheless, this building has the smallest daily cooling load compared to the other 496 building types. In general, the daily ceiling heat gains, cooling loads, and ceiling thermal 497 contribution in the total building cooling demand are larger for the buildings built before 1980. 

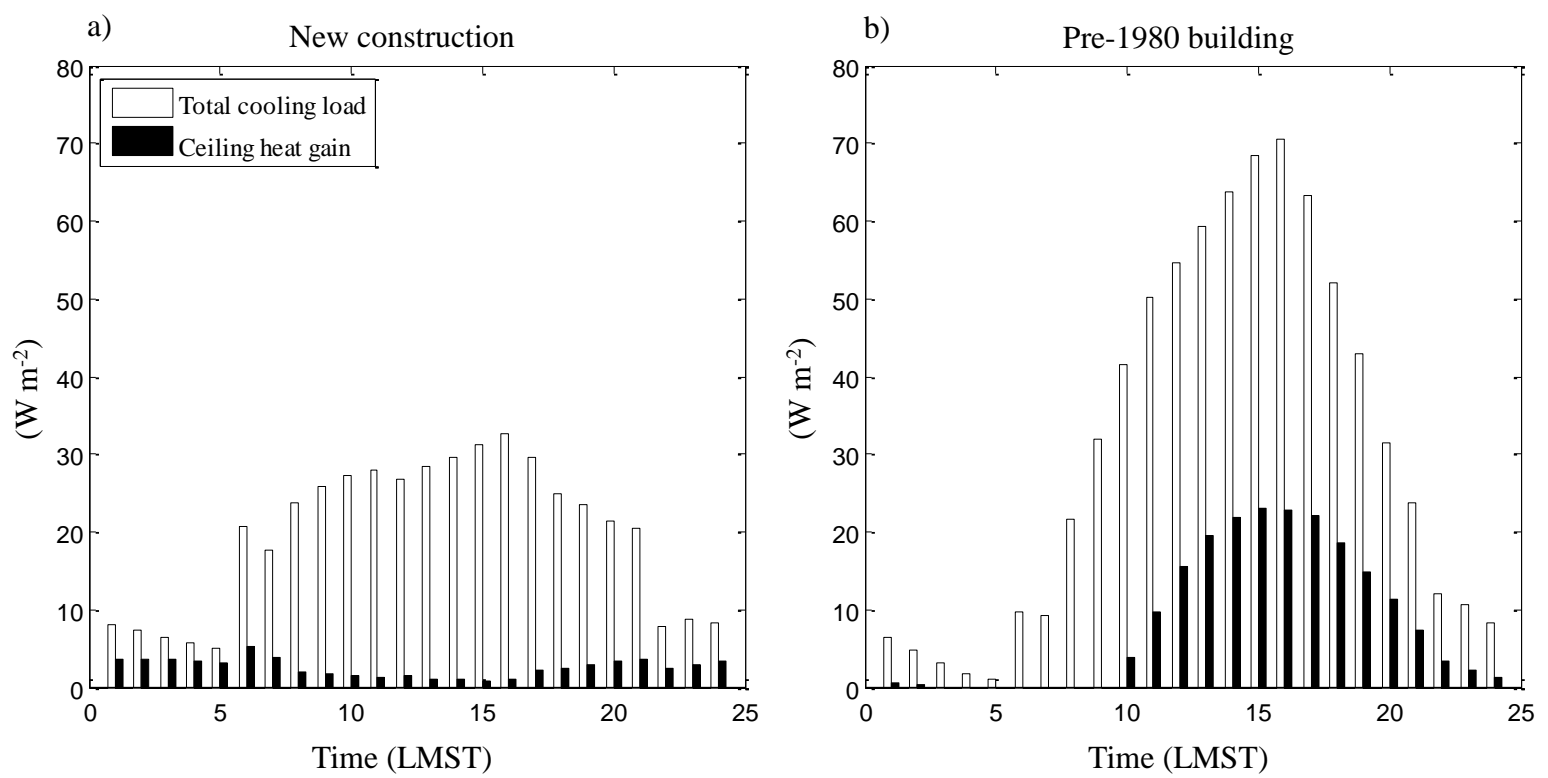

FIG. 7. Hourly comparisons of the ceiling heat gains (black bars) and total cooling loads (white bars) of the (a) newconstruction and (b) pre-1980 small office buildings with conventional roofs in $\mathrm{W} \mathrm{m}^{-2}$ of floor area for a typical summer day (monthly averaged diurnal cycles for the month of July) in Phoenix, AZ.

TABLE 4. Daily integrated values of ceiling heat gains and cooling loads in $\mathrm{Wh} \mathrm{m}^{-2}$ of floor area, and percentage of ceiling thermal contributions in the total cooling demands of the buildings with conventional roofs for a typical summer day (monthly averaged diurnal cycle over July) in Phoenix, AZ.

\begin{tabular}{cccc}
\hline Building type & $\begin{array}{c}\text { Ceiling heat gain } \\
\left(\mathrm{Wh} \mathrm{m}^{-2}\right)\end{array}$ & $\begin{array}{c}\text { Total cooling loads } \\
\left(\mathrm{Wh} \mathrm{m}^{-2}\right)\end{array}$ & $\begin{array}{c}\text { Ceiling thermal } \\
\text { contribution in total } \\
\text { cooling demand (\%) }\end{array}$ \\
\hline Office - new const. & 62 & 468 & 13 \\
Retail - new const. & 126 & 370 & 34 \\
Office - post-1980 & 80 & 569 & 14 \\
Retail - post-1980 & 89 & 549 & 26 \\
Office - pre-1980 & 198 & 742 & 33 \\
Retail - pre-1980 & 199 & 599 & \\
\hline
\end{tabular}




\subsection{Comparisons with the 'Ecoroof' model in EnergyPlus}

509 The present study introduced a new green roof model into EnergyPlus to account for the plant coverage percentage via parallel thermal circuits in the green roof simulations. This model

511 implementation benefited from an existing green roof model, called 'Ecoroof', already available

512 in EnergyPlus [21]. The introduced green roof model has new simulation module for the heat

513 transfer simulations, but it uses the water balance module available in the 'Ecoroof' model.

514 Furthermore, the existing 'Ecoroof' model provides an opportunity to directly compare simulation 515 results of the two models.

516 For the base-case, simulation results of 'Ecoroof' for a typical summer day in Phoenix, was 517 compared against the results of the new green roof model. The two models are different in their 518 plant and soil sensible and latent heat flux calculations. However, the major difference between 519 the two models is that the 'Ecoroof' model considers fully-covered green roofs, whereas the new 520 green roof model takes the plant coverage into account. As a result, 'Ecoroof' solves energy

521 balance equations for the plants and the soil underneath the plant layer, but the new green roof 522 model solves an additional energy balance equation for the bare portions of green roofs. Therefore, 523 the system of heat transfer equations is different due to different representation of the physical 524 system involving different thermal circuits. Nevertheless, the physical system is the same, so the 525 models should produce similar results under similar physical conditions. The comparison of green 526 roof substrate surface temperature, ceiling heat flux, and building thermal loads showed that the 527 results from the 'Ecoroof' model are similar to those of the 50\%-covered green roof model. Since 528 energy modeling of buildings involves many uncertainties with the input parameters, such as the 529 green roof coverage rate, using the 'Ecoroof' model can be considered equivalent to the use of the 530 new green roof model with $50 \%$ plant coverage. 


\section{5. Conclusions}

533 The temperature of a green roof substrate surface that affects energy use in buildings, primarily 534 depends on the amount of the total radiation absorbed by the surface, the substrate moisture 535 content, and the substrate thermal properties. Despite the fact that these parameters are affected by 536 the amount of plants covering the green roof soil surface, and considering that green roofs are not

537 always fully covered with plants, previous numerical studies simulated fully-covered green roofs. 538 A green roof model that takes into account the plant coverage percentage is implemented into 539 EnergyPlus and validated to investigate the effects of green roof plant coverage on the green roof 540 substrate surface energy balance and building energy consumption. Sensitivity of the results to the 541 local climate, building age, and building type are also investigated. The results show that green 542 roofs have a different thermal performance with different plant coverage, which affect the energy 543 demand in buildings. In general, the green roof substrate surface temperature decreases with an 544 increase in plant coverage predominantly due to the decrease in the amount of received solar 545 radiation at the soil surface as well as the increase in the amount of near surface moisture content 546 and soil surface evaporation. For the base-case simulation, the integrated value of total received 547 radiation at the bare-soil substrate surface is $32 \%\left(6.2 \mathrm{kWh} \mathrm{m}^{-2}\right)$ larger than the total radiation 548 received at the fully-covered green roof soil surface. Additionally, the total daily value of latent 549 heat fluxes over the bare-soil roof is negligible compared to that value over the fully-covered green 550 roof. For the base-case, the daily peak value of the substrate surface temperature for the bare-soil 551 roof is $24^{\circ} \mathrm{C}(34 \%)$ higher than that over the fully-covered green roof. The results of this study 552 also show that for the studied buildings located in climate zones 2 and 4, the annual cooling loads 553 decrease with the increased plant coverage rate. The opposite is true for the heating loads that 
554 increase with the increased plant coverage rate. However, in response to the change in plant 555 coverage, the decrease in the annual cooling demand is significantly larger than the increase in the 556 annual heating demand. For example, for the base-case simulation, the annual cooling loads 557 decrease with the rate of $13 \mathrm{kWh} \mathrm{m}^{-2}$ of plant coverage area, and the annual heating load increases 558 with the rate of $0.88 \mathrm{kWh} \mathrm{m}^{-2}$ of plant coverage area.

559 The results show that for a weak insulation of a roof on the pre-1980 office buildings, the maximum 560 surface temperature of the fully-covered green roof is $34 \%$ cooler than that of the bare-soil roof in 561 a typical summer day in Phoenix. This temperature difference results in 5\% decrease of the 562 building cooling demand during that time period. In this study, the green roof plant coverage 563 effects on the building cooling demand were only accounted by roof/ceiling conduction heat 564 transfer, so the cooling effects of green roofs on the outdoor air temperature is not considered in 565 the simulations. Green roofs, considered as one of the effective urban heat island mitigations, affect 566 the outdoor air temperature through convective heat transfer. In addition, in response to the 567 reduction in building energy use, the amount of discharged anthropogenic heat flux into outdoor 568 air decreases. These effects, and a dynamic simulation of outdoor air temperature are not included 569 in EnergyPlus. Despite the fact that the immediate effects of green roofs on building energy use 570 through conductive heat fluxes are more effective than their convective indirect effects, it is 571 anticipated that in the presence of a dynamic air temperature simulation, green roofs, and thus their 572 plant coverage, affect the indoor environment and building energy demand more effectively. The 573 importance of this factor is expected to be larger in urban areas with a larger surface areas covered 574 by green roofs. It is desirable to consider these effects in future studies. 
a)

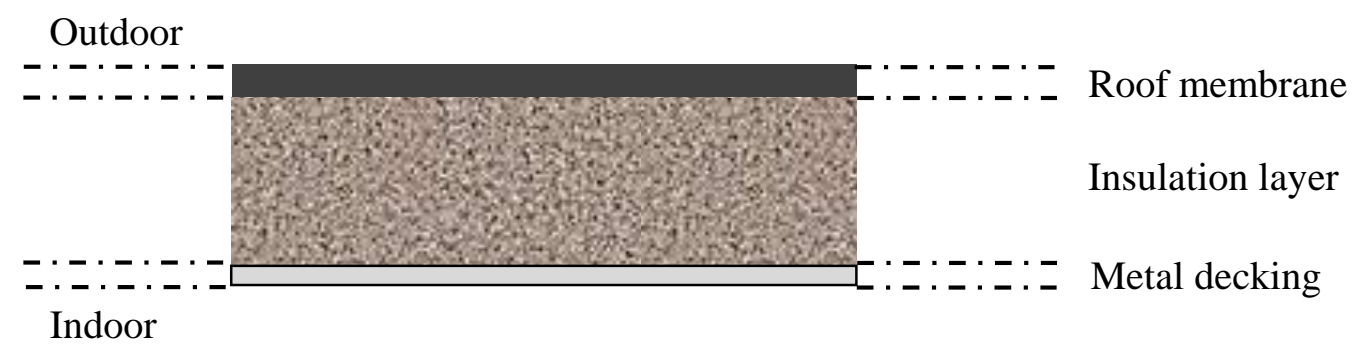

b)

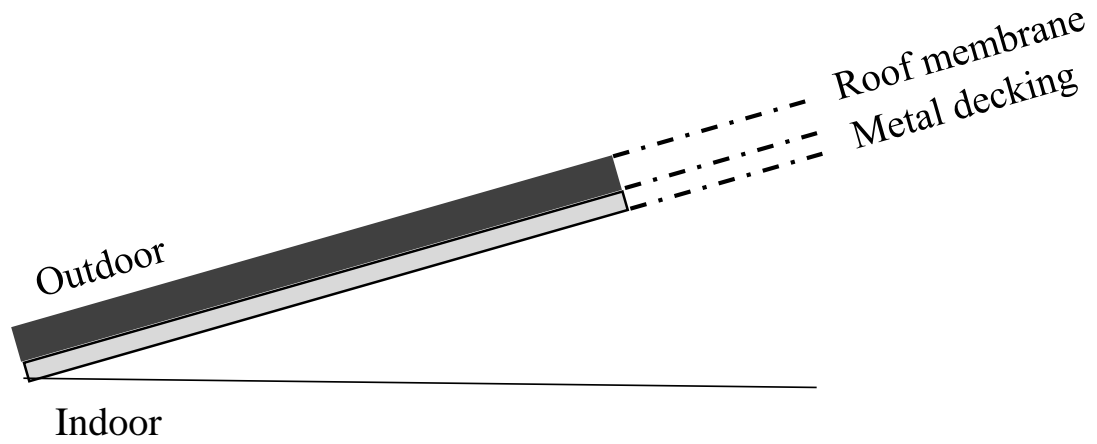

c)

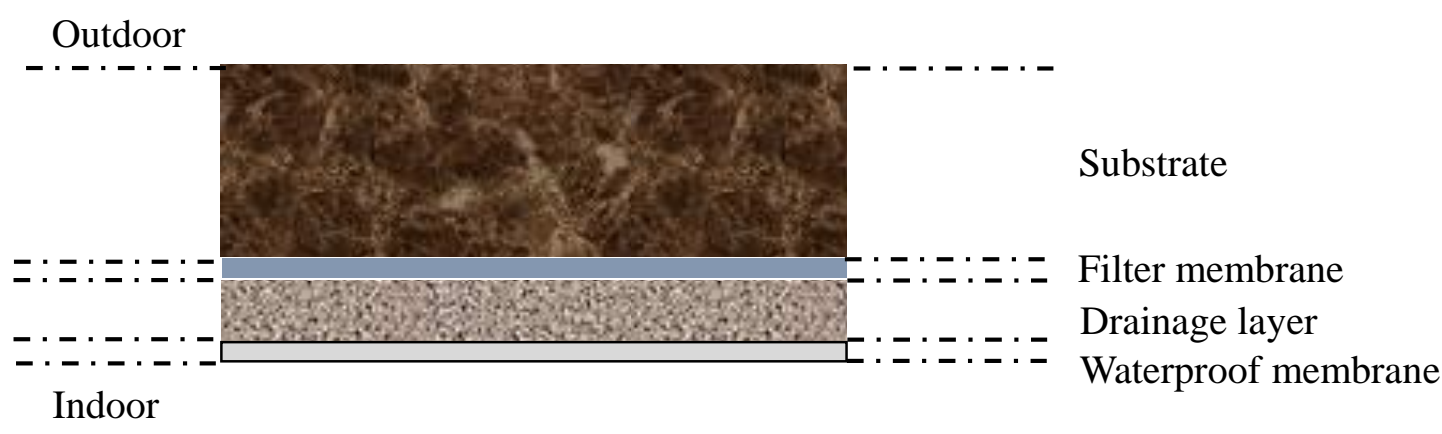

FIG. A1. Sketch of the layers of the a) IEAD non-residential b) attic non-residential, and c) green roofs that are used in the simulations. Thicknesses of the layers are not scaled in the figure. Thicknesses and physical characteristics of the material layers are provided in Table 1 and 2. 


\section{7. Acknowledgments}

586 This study is sponsored by the EFRI-1038264/EFRI-1452045 award from the National Science

587 Foundation (NSF), Division of Emerging Frontiers in Research and Innovation (EFRI). In

588 addition, authors would like to thank Prof. Paulo Tabares-Velasco at the Colorado School of Mines

589 for his valuable inputs.

590

591 


\section{References}

[1] W.G. Hansen, How accessibility shapes land use, J. Am. Inst. Plann. 25 (1959) 73-76.

[2] S.J. Stankowski, Population density as an indirect indicator of urban and suburban landsurface modifications, US Geological Survey Professional Paper. 800 (1972) 219-224.

[3] H. Akbari, L. Shea Rose, H. Taha, Analyzing the land cover of an urban environment using high-resolution orthophotos, Landscape Urban Plann. 63 (2003) 1-14.

[4] U. Berardi, A. GhaffarianHoseini, A. GhaffarianHoseini, State-of-the-art analysis of the environmental benefits of green roofs, Appl. Energy. 115 (2014) 411-428.

[5] J. Mentens, D. Raes, M. Hermy, Green roofs as a tool for solving the rainwater runoff problem in the urbanized 21st century?, Landscape Urban Plann. 77 (2006) 217-226.

[6] V. Stovin, N. Dunnett, A. Hallam, Green roofs-getting sustainable drainage off the ground, 6th International Conference of Sustainable Techniques and Strategies in Urban Water Mangement (2007) 11-18.

[7] N.H. Wong, Y. Chen, C.L. Ong, A. Sia, Investigation of thermal benefits of rooftop garden in the tropical environment, Build. Environ. 38 (2003) 261-270.

[8] H. Takebayashi, M. Moriyama, Surface heat budget on green roof and high reflection roof for mitigation of urban heat island, Build. Environ. 42 (2007) 2971-2979.

[9] K. Liu, B. Bass, Performance of green roof systems, National Research Council Publications Archive, Canada. NRCC-47705 (2005).

[10] M. Zhao, P.C. Tabares-Velasco, J. Srebric, S. Komarneni, Comparison of green roof plants and substrates based on simulated green roof thermal performance with measured material properties, 13th Conference of International Building Performance Simulation Association, Chambéry, France, August 26-28 (2013).

[11] G. Virk, A. Jansz, A. Mavrogianni, A. Mylona, J. Stocker, M. Davies, The effectiveness of retrofitted green and cool roofs at reducing overheating in a naturally ventilated office in London: Direct and indirect effects in current and future climates, Indoor and Built Environment. 23 (2014) 504-520.

[12] J.C. Berndtsson, L. Bengtsson, K. Jinno, Runoff water quality from intensive and extensive vegetated roofs, Ecol. Eng. 35 (2009) 369-380.

[13] J. Yang, Q. Yu, P. Gong, Quantifying air pollution removal by green roofs in Chicago, Atmos. Environ. 42 (2008) 7266-7273. 
[14] P.C. Tabares-Velasco, J. Srebric, A heat transfer model for assessment of plant based roofing systems in summer conditions, Build. Environ. 49 (2012) 310-323.

[15] D. Li, E. Bou-Zeid, M. Oppenheimer, The effectiveness of cool and green roofs as urban heat island mitigation strategies, Environmental Research Letters. 9 (2014) 055002.

[16] S. Ouldboukhitine, R. Belarbi, D.J. Sailor, Experimental and numerical investigation of urban street canyons to evaluate the impact of green roof inside and outside buildings, Appl. Energy. 114 (2014) 273-282.

[17] M.J. Clark, Y. Zheng, Fertilizer Rate and Type Affect Sedum-vegetated Green Roof Mat Plant Performance and Leachate Nutrient Content, HortScience. 49 (2014) 328-335.

[18] E.P.D. Barrio, Analysis of the green roofs cooling potential in buildings, Energy Build. 27 (1998) 179-193.

[19] T.G. Theodosiou, Summer period analysis of the performance of a planted roof as a passive cooling technique, Energy Build. 35 (2003) 909-917.

[20] D.J. Sailor, A green roof model for building energy simulation programs, Energy Build. 40 (2008) 1466-1478.

[21] The U.S. Department of Energy (DOE), EnergyPlus Energy Simulation Software (http://apps1.eere.energy.gov/buildings/energyplus/energyplus_about.cfm).

[22] P.C. Tabares-Velasco, J. Srebric, Experimental quantification of heat and mass transfer process through vegetated roof samples in a new laboratory setup, Int. J. Heat Mass Transfer. 54 (2011) 5149-5162.

[23] P.C. Tabares-Velasco, M. Zhao, N. Peterson, J. Srebric, R. Berghage, Validation of predictive heat and mass transfer green roof model with extensive green roof field data, Ecol. Eng. 47 (2012) 165-173.

[24] D.B. Crawley, J.W. Hand, M. Kummert, B.T. Griffith, Contrasting the capabilities of building energy performance simulation programs, Build. Environ. 43 (2008) 661-673.

[25] DOE, Getting started with EnergyPlus - Basic Concepts Manual - Essential Information You Need about Running EnergyPlus, U.S. Department of Energy, 2013.

[26] N. Yaghoobian, P.C. Tabares-Velasco, M. Heidarinejad, J. Srebric, Green roof model with plant coverage rate. US Department of Energy, EnergyPlus Engineering Reference, and EnergyPlus Input Output Reference. (2015).

[27] M. Zhao, P.C. Tabares-Velasco, J. Srebric, S. Komarneni, R. Berghage, Effects of plant and substrate selection on thermal performance of green roofs during the summer, Build. Environ. 78 (2014) 199-211. 
656 [28] National Renewable Energy Laboratory (NREL), National Solar Radiation Data

657 Base; 1961- 1990: Typical Meteorological Year 2

658 (http://rredc.nrel.gov/solar/old_data/nsrdb/1961-1990/tmy2/).

659 [29] M. Deru, K. Field, D. Studer, K. Benne, B. Griffith, P. Torcellini, B. Liu, M. Halverson, D. 660 Winiarski, M. Rosenberg, US Department of Energy commercial reference building models of 661 the national building stock (2011).

662 [30] Pacific Northwest National Laboratory, Advanced Energy Retrofit Guide, Retail Buildings 663 (2011).

664 [31] A. Niachou, K. Papakonstantinou, M. Santamouris, A. Tsangrassoulis, G. Mihalakakou, 665 Analysis of the green roof thermal properties and investigation of its energy performance, 666 Energy Build. 33 (2001) 719-729.

667 [32] H. Castleton, V. Stovin, S. Beck, J. Davison, Green roofs; building energy savings and the 668 potential for retrofit, Energy Build. 42 (2010) 1582-1591.

669 [33] I. Jaffal, S. Ouldboukhitine, R. Belarbi, A comprehensive study of the impact of green roofs 670 on building energy performance, Renewable Energy. 43 (2012) 157-164.

671 [34] The U.S. Department of Energy (DOE), Commercial Reference Buildings

672 (http://energy.gov/eere/buildings/commercial-reference-buildings).

673 [35] ASHRAE (Ed.), Energy Standard for Buildings Except Low-Rise Residential 674 Buildings. ANSI/ ASHRAE/IESNA Standard 90.1-2004, American Society of Heating, 675 Refrigerating and Air-Conditioning Engineers, Atlanta, GA, 2004.

676 [36] ASHRAE (Ed.), Energy Efficient Design of New Buildings Except Low-Rise 677 Residential Buildings. ANSI/ASHRAE/IESNA Standard 90.1-1989, American Society of 678 Heating, Refrigerating and Air-Conditioning Engineers, Atlanta, GA, 1989.

679 [37] M. Lewin, E.M. Pearce (Eds.), Handbook of Fiber Chemistry, Second Edition, Revised and 680 Expanded, 2nd ed., CRC Press, 1998.

681 [38] A. Lyons, Materials for Architects and Builders, forth ed., Elsevier Ltd, 2010.

682 [39] W.V. Titow (Ed.), PVC Technology, fourth ed., Elsevier Applied Science publishers, New 683 York, USA, 1984.

684 [40] ASM International, Characterization and Failure Analysis of Plastics, Library of Congress 685 Cataloging-in-Publication Data, United States of America, 2003.

686 [41] P. Tabares-Velasco, J. Srebrić, The role of plants in the reduction of heat flux through green 687 roofs: laboratory experiments, Klimatizacija, grejanje, hlađenje. 38 (2009) 55-62. 